AperTO - Archivio Istituzionale Open Access dell'Università di Torino

\title{
Phase diagrams of the LiBH4-NaBH4-KBH4 system
}

\section{This is a pre print version of the following article:}

Original Citation:

Availability:

This version is available http://hdl.handle.net/2318/1659729

since 2018-02-10T20:10:23Z

Published version:

DOI:10.1039/c7cp03816j

Terms of use:

Open Access

Anyone can freely access the full text of works made available as "Open Access". Works made available under a Creative Commons license can be used according to the terms and conditions of said license. Use of all other works requires consent of the right holder (author or publisher) if not exempted from copyright protection by the applicable law. 
Dematteis et al. - Phase diagrams in the $\mathrm{LiBH}_{4}-\mathrm{NaBH}_{4}-\mathrm{KBH}_{4}$ system

\section{Phase diagrams in the $\mathrm{LiBH}_{4}-\mathrm{NaBH}_{4}-\mathrm{KBH}_{4}$ system}

Erika M. Dematteis, ${ }^{\text {a)b })}$ Eugenio R. Pinatel, ${ }^{\text {a) }}$ Marta Corno, ${ }^{\text {a) }}$ Torben R. Jensen ${ }^{\text {b) }}$ and Marcello Baricco $^{\text {a)* }}$

${ }^{a)}$ Department of Chemistry and Inter-departmental Center Nanostructured Interfaces and Surfaces (NIS), University of Turin, Via Pietro Giuria 7, 10125 Torino, Italy

${ }^{b}$ Department of Chemistry, Center for Materials Crystallography (CMC) and Interdisciplinary Nanoscience Center (iNANO) Aarhus University, Langelandsgade 140, DK-8000 Aarhus C, Denmark

*Corresponding author

Marcello Baricco

E-mail address: marcello.baricco@ unito.it

Tel.: +390116707569

Fax: +390116707856 
Dematteis et al. - Phase diagrams in the $\mathrm{LiBH}_{4}-\mathrm{NaBH}_{4}-\mathrm{KBH}_{4}$ system

\begin{abstract}
A combination of experimental and computational techniques has been used to fully describe the thermodynamic properties and phase diagrams of the $\mathrm{LiBH}_{4}-\mathrm{NaBH}_{4}-\mathrm{KBH}_{4}$ system. The Calphad method was used to assess the thermodynamic properties of $\mathrm{LiBH}_{4}-\mathrm{NaBH}_{4}, \mathrm{LiBH}_{4}-\mathrm{KBH}_{4}$, and $\mathrm{NaBH}_{4}-\mathrm{KBH}_{4}$ binary systems and to extend the investigation to the $\mathrm{LiBH}_{4}-\mathrm{NaBH}_{4}-\mathrm{KBH}_{4}$ ternary system. Samples with various compositions in the ternary system were synthetised, both by ball milling and manual mixing of the parent borohydrides, and their thermal stability has been studied by in-situ synchrotron radiation X-ray diffraction as a function of temperature and by differential scanning calorimetry. From collected experimental and literature data, a thermodynamic assessment of the ternary system led to the determination of the phase diagrams. In all cases, the solid solutions can be described in the frame of the regular solution model, with interaction parameters positive or equal to zero (i.e. ideal solution). On the contrary, the liquid phase was described using negative interaction parameters. A new ternary eutectic composition was estimated and it was confirmed experimentally to be equal to a molar fraction of $0.66 \mathrm{LiBH}_{4}-0.11 \mathrm{NaBH}_{4}-0.23 \mathrm{KBH}_{4}$ with a melting temperature of $102^{\circ} \mathrm{C}$.
\end{abstract}

Keywords: complex hydrides, lithium borohydride, sodium borohydride, potassium borohydride hydrogen storage, phase diagram, Calphad. 
Dematteis et al. - Phase diagrams in the $\mathrm{LiBH}_{4}-\mathrm{NaBH}_{4}-\mathrm{KBH}_{4}$ system

\section{Introduction}

Recent research has focused on solid-state hydrogen storage in complex hydrides owing to their high gravimetric hydrogen content. ${ }^{1-5}$ However, the kinetic and thermodynamic limitation of these compounds has to be addressed and different approaches have been described in the literature to improve them. ${ }^{6-8}$ For instance, the melt infiltration of eutectic mixtures of borohydrides ${ }^{9}$ into mesoporous carbon scaffolds improves the kinetics and reversibility of hydrogen release. ${ }^{10-14}$ Solid solutions of borohydrides have shown lower temperature of hydrogen release ${ }^{15-18}$ and could be of interest as solid-state electrolyte in batteries.

A full evaluation of the thermodynamic properties of borohydrides and their mixtures is indeed fundamental for tailoring hydrogen storage materials, as well as for further improvements and insight on complex hydrides. The use of the Calphad approach for the assessment of the phase diagrams in complex hydrides allowed the determination of different thermodynamic properties and possible decomposition routes or hydrogen release reactions, together with the enthalpy of mixing in the liquid and solid solutions, which cannot be easily determined experimentally. ${ }^{19-22}$

The Calphad method for the assessment of thermodynamic properties in condensed systems is based on a parametric description of the Gibbs free energy as a function of temperature and composition. Literature data and new experimental results on thermodynamic properties were collected for the studied system and they are used as input data. In order to establish the Gibbs free energy of compounds with crystal structures different from the stable one, ab-initio calculations are often necessary. A process of optimization by best fitting allows the assessment of parameters in order to have the most reliable description of Gibbs free energy for all phases in the system based on the input values. The description of the ternary system can be obtained from the evaluation of thermodynamic properties of binary systems in order to calculate pseudo-binary and pseudo-ternary phase diagrams. In the literature, it was showed that binary combination of $\mathrm{LiBH}_{4}, \mathrm{NaBH}_{4}$, and $\mathrm{KBH}_{4}$ present eutectic melting ${ }^{23,24}$ or a thermal minimum. ${ }^{15}$ 
Dematteis et al. - Phase diagrams in the $\mathrm{LiBH}_{4}-\mathrm{NaBH}_{4}-\mathrm{KBH}_{4}$ system

The $\mathrm{LiBH}_{4}-\mathrm{NaBH}_{4}$ system was recently studied and modelled by the present authors ${ }^{23}$ showing the formation of solid solutions on both lithium- and sodium-rich side and a eutectic melting at $216{ }^{\circ} \mathrm{C}$ for the composition $0.70 \mathrm{LiBH}_{4}-0.30 \mathrm{NaBH}_{4}$. In this system, the polymorphic transition from the orthorhombic to the hexagonal structure is observed at $95{ }^{\circ} \mathrm{C}$ in mixtures (i.e. $15^{\circ} \mathrm{C}$ lower than for pure $\left.\mathrm{LiBH}_{4}\right)$.

The $\mathrm{LiBH}_{4}-\mathrm{KBH}_{4}$ system was reported as eutectic by Ley et al. ${ }^{24}$ and Huff ${ }^{25}$ with a melting temperature of $105^{\circ} \mathrm{C}$ for the composition $0.72 \mathrm{LiBH}_{4}-0.28 \mathrm{KBH}_{4}$. The same phase diagram, but with a different eutectic composition, was reported by Adams in $1961 .{ }^{26}$ In this system, no solid solutions were observed. A bimetallic compound $\mathrm{LiK}\left(\mathrm{BH}_{4}\right)_{2}$ has been recently reported, which decomposes at $96{ }^{\circ} \mathrm{C}$ into $\mathrm{LiBH}_{4}$ and $\mathrm{KBH}_{4}$.

Two experimental studies have been reported for the $\mathrm{NaBH}_{4}-\mathrm{KBH}_{4}{ }^{15,27}$ system. Jensen et al. ${ }^{15}$ showed the formation of a solid solution and a minimum melting temperature at $458^{\circ} \mathrm{C}$ for the composition $0.68 \mathrm{NaBH}_{4}-0.32 \mathrm{KBH}_{4}{ }^{15} \mathrm{~A}$ miscibility gap has been evidenced below $200{ }^{\circ} \mathrm{C}$ in the bcc solid solution, which can be quenched at room temperature. The de-mixing kinetics of the solid solution at room temperature was studied by NMR. ${ }^{15}$

Considering the ternary $\mathrm{LiBH}_{4}-\mathrm{NaBH}_{4}-\mathrm{KBH}_{4}$ system, $\mathrm{Huff}^{25}$ reported a ternary eutectic melting at $96{ }^{\circ} \mathrm{C}$ for the $0.65 \mathrm{LiBH}_{4}-0.08 \mathrm{NaBH}_{4}-0.27 \mathrm{KBH}_{4}$ composition, but Paskevicius et al. ${ }^{9}$ reported no eutectic melting for that mixture.

No thermodynamic characterizations of the $\mathrm{LiBH}_{4}-\mathrm{NaBH}_{4}-\mathrm{KBH}_{4}$ ternary system are present in the literature so far. Therefore, in the present study, we explore this ternary system, combining experimental and theoretical techniques, in order to determine a pseudo-ternary phase diagram. The Calphad method was used to assess the thermodynamics of $\mathrm{LiBH}_{4}-\mathrm{NaBH}_{4}, \mathrm{LiBH}_{4}-\mathrm{KBH}_{4}$, and $\mathrm{NaBH}_{4}-\mathrm{KBH}_{4}$ binary systems, as well as a full investigation, for the first time, of the ternary system. For the assessment of solid solutions, the regular solution model was used, whereas the RedlichKister model was considered to describe the liquid phase. Results of the assessment allow the 
Dematteis et al. - Phase diagrams in the $\mathrm{LiBH}_{4}-\mathrm{NaBH}_{4}-\mathrm{KBH}_{4}$ system

establishing of phase stabilities and limits of solubility for a wide temperature and composition range in the ternary system.

\section{Experimental}

\section{Sample preparation}

Lithium borohydride $\left(\mathrm{LiBH}_{4}\right.$, purity > 99\% from Rockwood Lithium), sodium borohydride $\left(\mathrm{NaBH}_{4}\right.$, purity $99.99 \%$ from Sigma-Aldrich), and potassium borohydride $\left(\mathrm{KBH}_{4}\right.$, purity $99 \%$ from SigmaAldrich) were mixed by manual mixing (M) in a mortar or by ball milling (BM) in different molar ratios. A Fritsch Pulverisette 6 planetary mill was used to ball mill the reactants under argon atmosphere in $80 \mathrm{~mL}$ tungsten carbide (WC) vials and with WC balls (o.d. $10 \mathrm{~mm}$ ) and a balls-tosample mass ratio of 30:1. The samples were milled at 350 r.p.m. for $5 \mathrm{~min}$ for 24 times, with a $2 \mathrm{~min}$ pause in between each time. The mixtures manually mixed were finely homogenized in a mortar for 10 minutes. All preparations and manipulations of the samples were performed in an argon-filled glove box with a circulation purifier, $p\left(\mathrm{O}_{2}, \mathrm{H}_{2} \mathrm{O}\right)<1 \mathrm{ppm}$. An overview of investigated samples is reported in Table 1 and Figure S1.

\section{Characterization}

\section{In-situ time-resolved synchrotron radiation powder X-ray diffraction (SR-PXD)}

In-situ SR-PXD experiments have been carried out using different beam lines, as reported in Table S1. The measurements on sample T50Li, T50Na, and T50K were performed at beamline I711 at the MAX-II synchrotron in the MAXIV laboratories, Lund, Sweden, with a Titan CCD detector system, ${ }^{28}$ and using single crystal sapphire capillaries and a special setup. ${ }^{29}$ In the other facilities a sealed borosilicate capillary (o.d. $5 \mathrm{~mm}$ ) was used for samples T1, T2 and T3. The samples were packed and manipulated in a glove box. A hot air blower, equipped with a PID controller, was used to anneal the sample from RT up to the melting point at $5{ }^{\circ} \mathrm{C} / \mathrm{min}$. The temperature was recorded by a thermocouple placed close to the capillary and calibrated using $\mathrm{NaCl}$ (NIST) and $\mathrm{Ag}$ as a standard. The detector 
Dematteis et al. - Phase diagrams in the $\mathrm{LiBH}_{4}-\mathrm{NaBH}_{4}-\mathrm{KBH}_{4}$ system

distance was calibrated using $\mathrm{LaB}_{6}$ as a standard. The FIT2D program was used to convert the raw $2 \mathrm{D}$ images into $1 \mathrm{D}$ powder pattern. ${ }^{30}$

\section{Differential scanning calorimetry (DSC)}

A Perkin Elmer STA 6000 apparatus was used to analyse the thermal behaviour of the mixtures s1s8. Approximately $5 \mathrm{mg}$ of sample were loaded inside the glove box into aluminium crucibles with a lid with a hole for gas release. Afterwards, the pan was transported to the instrument using a sealed glass vial to maintain the inert atmosphere and quickly placed under the argon flow. Samples were heated and cooled in the temperature range from RT up to $130{ }^{\circ} \mathrm{C}$ at $5{ }^{\circ} \mathrm{C} / \mathrm{min}$ under an argon flow of $40 \mathrm{~mL} / \mathrm{min}$.

A high-pressure 204 Netsch DSC (HP-DSC) was used to analyse the mixture T1, T2, and T3 and a backpressure of hydrogen was loaded in the chamber in order to avoid the decomposition of the liquid and to record the liquidus temperature. Approximately $5 \mathrm{mg}$ of sample were loaded into aluminium crucibles with a lid with a hole for gas release. The HP-DSC was placed inside the glove box in order to handle the samples in inert atmosphere. Samples were heated and cooled in the temperature range from RT up to approx. $160{ }^{\circ} \mathrm{C}$ at $5{ }^{\circ} \mathrm{C} / \mathrm{min}$ under a static pressure of $10 \mathrm{bar}$ of $\mathrm{H}_{2}$.

\section{Modelling}

\section{Ab-initio}

Periodic quantum-mechanical calculations were carried out at the Density Functional Theory (DFT) level, by using a developmental version of the CRYSTAL14 software. ${ }^{31,32}$ As already described in a previous paper, ${ }^{23}$ we adopted the hybrid PBE0 functional, ${ }^{33}$ in combination with the Grimme's D2 correction to the electronic energy, ${ }^{34}$ as the best balance of accuracy and calculation cost. Localized Gaussian functions of double- $\zeta$ quality were applied as basis sets for the description of electrons. For the cations, the following sets were used: $5-11 \mathrm{G}(\mathrm{d})\left(\alpha_{\mathrm{sp}}=0.479 \mathrm{bohr}^{-2}\right.$ for the most diffuse shell exponent and $\alpha_{\mathrm{pol}}=0.600 \mathrm{bohr}^{-2}$ for polarization $)$ to describe lithium; 8-511G $\left(\alpha_{\mathrm{sp}}=0.323 \mathrm{bohr}^{-2}\right.$ for the most diffuse shell exponent) for sodium and 86-511G $\left(\alpha_{\mathrm{sp}}=0.389\right.$ and $\alpha_{\mathrm{d}}=0.394 \mathrm{bohr}^{-2}$ for the most diffuse shell exponent of sp and d functions) in the case of potassium. ${ }^{23,35}$ Boron was described 
Dematteis et al. - Phase diagrams in the $\mathrm{LiBH}_{4}-\mathrm{NaBH}_{4}-\mathrm{KBH}_{4}$ system

by a $6-21 \mathrm{G}(\mathrm{d})$ set $\left(\alpha_{\mathrm{sp}}=0.124 \mathrm{bohr}^{-2}\right.$ for the most diffuse shell exponent and $\alpha_{\mathrm{pol}}=0.800 \mathrm{bohr}^{-2}$ for polarization $)$ and for hydrogen, a $31 \mathrm{G}(\mathrm{p})$ set $\left(\alpha_{\mathrm{sp}}=0.1613 \mathrm{bohr}^{-2}\right.$ for the most diffuse shell exponent and $\alpha_{\mathrm{pol}}=1.1$ bohr $^{-2}$ for polarization) was adopted. ${ }^{35}$ The thermodynamic functions were obtained within the calculation of phonons at $\Gamma$ point in the harmonic approximation. Within the CRYSTAL code, frequencies are computed by diagonalizing the associated mass-weighted Hessian matrix. More details on the specific procedure can be found in references. ${ }^{36,37}$ To derive enthalpy data, the computed zero-point energy correction (ZPE) and the thermal factor at $\mathrm{T}=25^{\circ} \mathrm{C}$ were added to the obtained electronic energy. ${ }^{38}$

\section{CALPHAD}

The Thermo-Calc Software ${ }^{39}$ based on the Calphad approach was used for the thermodynamic assessment. The Substance SGTE database $\mathrm{e}^{40,41}$ and already published thermodynamic functions ${ }^{19,23}$ were used as a starting point for the assessment procedure. Assessed parameters of thermodynamic functions for different phases (hexagonal, cubic, orthorhombic and liquid) have been assessed in the present study, in order to explore and characterize the pseudo-binary and pseudo-ternary phase diagrams in the $\mathrm{LiBH}_{4}-\mathrm{NaBH}_{4}-\mathrm{KBH}_{4}$ system.

The thermodynamic properties and Gibbs free energy were described according to the Calphad approach, as previously reported..$^{23}$ The Redlich-Kister expansion series ${ }^{42}$ was used to describe the excess Gibbs energy of solutions, and for the $\mathrm{LiK}\left(\mathrm{BH}_{4}\right)_{2}$ compound a constant value of enthalpy and entropy of formation has been considered. The ortho- and hexagonal- $\mathrm{KBH}_{4}$ end-members were described adding the ab-initio calculated enthalpy difference between the stable and the metastable phases to the Gibbs energy of the stable ones.

\section{Results and Discussion}

\section{Experimental screening of ternary system}

Three different compositions close to the centre of the pseudo-ternary phase diagram were synthesized by ball milling and have been characterized by in-situ SR-PXD. Samples T50Li, T50Na 
Dematteis et al. - Phase diagrams in the $\mathrm{LiBH}_{4}-\mathrm{NaBH}_{4}-\mathrm{KBH}_{4}$ system

and $\mathrm{T} 50 \mathrm{~K}$ were annealed with a heating rate of $5{ }^{\circ} \mathrm{C} / \mathrm{min}$ to investigate the formation of different phases in the system.

In T50Li (Figure S2), the polymorphic transition orthorhombic to hexagonal $\mathrm{LiBH}_{4}$ is recorded at $109{ }^{\circ} \mathrm{C}$, and at $112{ }^{\circ} \mathrm{C}$ the $\mathrm{LiBH}_{4}-\mathrm{KBH}_{4}$ eutectic melts. There is no evidence of any ternary eutectic melting or solid solutions in the temperature range $112^{\circ} \mathrm{C}$ to $323^{\circ} \mathrm{C}$, where the melting of the sample is observed to start.

In $\mathrm{T} 50 \mathrm{Na}$ (Figure S3), the polymorphic phase transition of $\mathrm{LiBH}_{4}$ is not clearly observed, and the orthorhombic $\mathrm{LiBH}_{4}$ melts at $114{ }^{\circ} \mathrm{C}$. The formation of a cubic solid solution between the remaining $\mathrm{NaBH}_{4}$ and $\mathrm{KBH}_{4}$ is observed in the temperature range $114{ }^{\circ} \mathrm{C}$ to $215^{\circ} \mathrm{C}$ as two sets of Bragg diffraction peaks merge into one. At $215{ }^{\circ} \mathrm{C}$, diffraction peaks of $\mathrm{KBH}_{4}$ disappear, and a single cubic solid solution is observed. An excess of $\mathrm{NaBH}_{4}$ is also recorded, which disappears at $274{ }^{\circ} \mathrm{C}$. The liquidus temperature is observed at $375^{\circ} \mathrm{C}$.

In T50K sample (Figure S4), the polymorphic transition of $\mathrm{LiBH}_{4}$ is recorded at $110{ }^{\circ} \mathrm{C}$, at which point the onset of the eutectic melting of $\mathrm{LiBH}_{4}-\mathrm{KBH}_{4}$ is also observed. At $185{ }^{\circ} \mathrm{C}$, the crystalline fraction of the sample consists of a cubic solid solution of $\mathrm{NaBH}_{4}-\mathrm{KBH}_{4}$, which is rich in $\mathrm{NaBH}_{4}$. The solid solution starts to melt at $352^{\circ} \mathrm{C}$ and the liquidus temperature is recorded at $479{ }^{\circ} \mathrm{C}$.

In none of these samples the bimetallic $\mathrm{LiK}\left(\mathrm{BH}_{4}\right)_{2}$ is observed.

This first screening of the $\mathrm{LiBH}_{4}-\mathrm{NaBH}_{4}-\mathrm{KBH}_{4}$ ternary system, conducted by in-situ SR-PXD, did not allow identifying any ternary eutectic composition. So, data collected in this experimental study will be used for a preliminary thermodynamic assessment of the system, leading to a first approximation of the pseudo-ternary phase diagram and to give a hint of the ternary eutectic composition, as will be discussed later.

\section{Assessment of binary systems}

The thermodynamic assessment of the possible binary combinations in the $\mathrm{LiBH}_{4}-\mathrm{NaBH}_{4}-\mathrm{KBH}_{4}$ systems allowed the modelling of solid and liquid solution phases. Consistent literature and experimental data together with ab-initio calculations and available database have been used as input 
Dematteis et al. - Phase diagrams in the $\mathrm{LiBH}_{4}-\mathrm{NaBH}_{4}-\mathrm{KBH}_{4}$ system

for the full assessment and description of pseudo-binary phase diagrams and for a first investigation of the ternary system.

\section{$\mathrm{NaBH}_{4}-\mathrm{KBH}_{4}$}

The $\mathrm{NaBH}_{4}-\mathrm{KBH}_{4}$ system was modelled considering experimental data obtained by both Jensen et al. ${ }^{15}$ and Semenenko et al. ${ }^{27}$ The cubic phase was modelled considering the formation of a solid solution with a miscibility gap, as confirmed experimentally by Jensen et al., ${ }^{15}$ so that a positive value of the enthalpy of mixing was assessed (Table 2). For a proper modelling of the liquid phase, in order to optimise the enthalpy of melting for the composition with the lowest melting point, a revision of the thermodynamic description of the liquid phase of pure $\mathrm{NaBH}_{4}$ was necessary. Pure $\mathrm{NaBH}_{4}$ was previously described to have an enthalpy of melting equal to $26.9 \mathrm{~kJ} / \mathrm{mol},{ }^{23}$ as obtained experimentally in ref. ${ }^{43}$ Considering that a lower value equal to $16.9 \mathrm{~kJ} / \mathrm{mol}$ was reported by Milanese et al., ${ }^{44}$ a new function for the liquid phase of $\mathrm{NaBH}_{4}$ was considered (Table 3). The enthalpy of melting for pure $\mathrm{KBH}_{4}$ has never been reported in the literature and it is not easy to measure, since it melts and decomposes at the same time. ${ }^{45} \mathrm{~A}$ melting temperature equal to $605^{\circ} \mathrm{C}$ was considered, as experimentally observed by Paskevicius et al. ${ }^{9}$ and Stasinevich et al. ${ }^{45}$ The enthalpy of melting for $\mathrm{KBH}_{4}$ was first estimated and then progressively refined during the whole assessment process, leading to a value of $19.2 \mathrm{~kJ} / \mathrm{mol}$. On the basis of assessed thermodynamic functions for pure $\mathrm{NaBH}_{4}$ and $\mathrm{KBH}_{4}$, the liquid phase in the $\mathrm{NaBH}_{4}-\mathrm{KBH}_{4}$ system has been described with a slightly positive interaction parameter, obtaining a calculated enthalpy of melting for the composition $0.68 \mathrm{NaBH}_{4}$ $0.32 \mathrm{KBH}_{4}$ higher than that reported in the literature. ${ }^{15}$ The same sample was measured again under 10 bar of hydrogen, and an enthalpy of melting of $17.0 \mathrm{~kJ} / \mathrm{mol}$ was obtained during cooling (Figure S5), in good agreement with the calculated value (Table 4). Assessed functions of Gibbs free energy are reported in Table 3. The calculated $\mathrm{NaBH}_{4}-\mathrm{KBH}_{4}$ pseudo-binary phase diagram is shown in Figure 1 a, together with available experimental data. The miscibility gap in the cubic phase is well reproduced, as well as the melting temperatures. For $\mathrm{KBH}_{4}$-rich compositions, the calculated values 
Dematteis et al. - Phase diagrams in the $\mathrm{LiBH}_{4}-\mathrm{NaBH}_{4}-\mathrm{KBH}_{4}$ system

are higher than the experimental ones, suggesting an underestimation of solidus temperatures, which turned out rather constant as a function of composition. ${ }^{15}$

\section{$\mathrm{LiBH}_{4}-\mathrm{NaBH}_{4}$}

Considering the new thermodynamic description of pure $\mathrm{NaBH}_{4}$, the $\mathrm{LiBH}_{4}-\mathrm{NaBH}_{4}$ binary system was re-assessed and a good agreement with the experimental value of enthalpy of melting for the eutectic mixture was achieved (Table 2), leading to a lower calculated enthalpy of mixing for the liquid phase with respect to the previous assessment. ${ }^{23}$ Available experimental data and calculated pseudo-binary phase diagrams are reported in Figure $\mathbf{1}$ b, confirming the good agreement obtained with the new thermodynamic description.

\section{$\mathrm{LiBH}_{4}-\mathrm{KBH}_{4}$}

Since the $\mathrm{LiBH}_{4}-\mathrm{KBH}_{4}$ system was recently experimentally characterised, only the data from Ley et al. ${ }^{24}$ were considered for the assessment, while Adams' values ${ }^{26}$ have been taken into account only for comparison. Ab-initio results reported in Table 5 were used to describe the Gibbs free energy of the $\mathrm{KBH}_{4}$ end-members (i.e. orthorhombic and hexagonal phase). In the solid state, three phases are present in this system: orthorhombic, hexagonal, and cubic. In addition, up to $96{ }^{\circ} \mathrm{C}$, also the bimetallic compound $\mathrm{LiK}\left(\mathrm{BH}_{4}\right)_{2}$ is present. The Gibbs free energy function for the bimetallic compound has been determined combining the calculated value of the enthalpy of formation from $\mathrm{LiBH}_{4}$ and $\mathrm{KBH}_{4}$ reported by Kim at al. ${ }^{46}$ with the temperature of decomposition reported by Ley et al. ${ }^{24}$ This is reported in Table 3. Since no solid solutions are observed experimentally, the solid phases were described with a positive interaction parameter to reduce the solubility limit (Table 2). In the frame of the regular solution model, a negative value of the interaction parameter has been used for the liquid phase in order to describe the deep eutectic. It has been optimized on the basis of the temperature and enthalpy of melting of the eutectic composition. The calculated pseudo-binary phase diagram is reported in Figure 1 c, together with available experimental data. Experimental data of eutectic composition and temperatures reported by Ley et al. ${ }^{24}$ are in good agreement with 
Dematteis et al. - Phase diagrams in the $\mathrm{LiBH}_{4}-\mathrm{NaBH}_{4}-\mathrm{KBH}_{4}$ system

calculations. Liquidus temperatures reported by Ley et al. ${ }^{24}$ are reasonably reproduced, whereas those observed by Adams ${ }^{26}$ appear significantly different.

\section{Ternary system}

A eutectic composition has been reported by Huff et al., ${ }^{25}$ as indicated by a red triangle (T1) in the pseudo-ternary $\mathrm{LiBH}_{4}-\mathrm{NaBH}_{4}-\mathrm{KBH}_{4}$ phase diagram shown in Figure 2, but it was evidenced as not eutectic by Paskevicius et al. ${ }^{9}$ So, the T1 composition was investigated by DSC and in-situ SR-PXD. A first heating up-and-down to melting was necessary to homogenise the sample. The DSC traces and SR-PXD patterns during the second cycle of heating and cooling of the mixture are shown in Figure S6. During heating, the orthorhombic-to-hexagonal polymorphic transition can be observed at $97{ }^{\circ} \mathrm{C}$ (DSC) and $95{ }^{\circ} \mathrm{C}$ (SR-PXD). It appears at lower temperature with respect to pure $\mathrm{LiBH}_{4}{ }^{19}$ because of the presence of $\mathrm{NaBH}_{4}$, and possibly of $\mathrm{KBH}_{4}$, in the orthorhombic solid solution. An eutectic melting temperature of $\mathrm{T}_{\text {onset }}=103{ }^{\circ} \mathrm{C}$ (DSC) and $104{ }^{\circ} \mathrm{C}$ (SR-PXD) was observed, whereas the liquidus temperature observed at $155^{\circ} \mathrm{C}$ (SR-PXD) was difficult to defined by DSC (Figure S6). During cooling, the liquidus temperature was estimated at $148{ }^{\circ} \mathrm{C}$ and $146^{\circ} \mathrm{C}$ by DSC and SR-PXD, respectively, and other phase transformations were also observed at lower temperatures because of undercooling.

Initially, the enthalpy of mixing of the liquid phase for the ternary system was simply extrapolated from those of the binary systems by using the Muggianu's rule. ${ }^{47,48}$ The assessment of the pseudoternary phase diagram allowed the calculation of the minima of the liquidus surface, as shown by black solid lines in Figure 2. The ternary composition at the crossing of lines was calculated at $0.68 \mathrm{LiBH}_{4}-0.08 \mathrm{NaBH}_{4}-0.24 \mathrm{KBH}_{4}$, and it is shown as a black circle (T2) in Figure 2. The corresponding calculated melting temperature of $116^{\circ} \mathrm{C}$ turned out higher than that of the eutectic in the $\mathrm{LiBH}_{4}-\mathrm{KBH}_{4}$ system, excluding a eutectic reaction. For this reason, the $0.68 \mathrm{LiBH}_{4}-0.08 \mathrm{NaBH}_{4}-$ $0.24 \mathrm{KBH}_{4}$ composition was investigated by DSC and in-situ SR-PXD, and results are reported in Figure S7. From the SR-PXD data, it is clearly observed that the sample is not eutectic and that it contains an excess of $\mathrm{KBH}_{4}$. In fact, on heating, we observed a strong reduction of X-ray intensity at 
Dematteis et al. - Phase diagrams in the $\mathrm{LiBH}_{4}-\mathrm{NaBH}_{4}-\mathrm{KBH}_{4}$ system

$104{ }^{\circ} \mathrm{C}$ representative of melting onset, where most of the $\mathrm{NaBH}_{4}$ transforms into liquid (Figure S7). In a small, higher temperature range, both orthorhombic and hexagonal $\mathrm{LiBH}_{4}$ have been observed, which melted at $121{ }^{\circ} \mathrm{C}$, so that only $\mathrm{KBH}_{4}$ was left up to $145^{\circ} \mathrm{C}$, corresponding to the liquidus temperature. On cooling, the excess of $\mathrm{KBH}_{4}$ crystallized at $143{ }^{\circ} \mathrm{C}$, then hexagonal $\mathrm{LiBH}_{4}$ and cubic $\mathrm{NaBH}_{4}$ appeared at $102{ }^{\circ} \mathrm{C}$ and a fully solid mixture was observed at $99^{\circ} \mathrm{C}$. The DSC data confirmed the phase transformations observed by SR-PXD, allowing the liquidus temperature to be better observed around $128{ }^{\circ} \mathrm{C}$. The observed phase transformations confirm that the $0.68 \mathrm{LiBH}_{4-}$ $0.08 \mathrm{NaBH}_{4}-0.24 \mathrm{KBH}_{4}$ mixture is not eutectic and suggest that the real ternary composition should contain less $\mathrm{LiBH}_{4}$ and $\mathrm{KBH}_{4}$.

These results motivated the assessment of the ternary system introducing an interaction parameter for the liquid phase in order to obtain a ternary eutectic temperature of $102{ }^{\circ} \mathrm{C}$. So, a further interaction parameter for the liquid phase was added, according to Redlich-Kister-Muggianu equation: ${ }^{48}$

$$
\begin{aligned}
& { }_{T E R} G_{m}^{e x c}=x_{a} x_{b}\left\{{ }^{0} L_{a b}+{ }^{1} L_{a b}\left(x_{a}-x_{b}\right)\right\}+x_{a} x_{c}\left\{{ }^{0} L_{a c}+{ }^{1} L_{a c}\left(x_{a}-x_{c}\right)\right\}+x_{b} x_{c}\left\{{ }^{0} L_{b c}+\right. \\
& \left.{ }^{1} L_{b c}\left(x_{b}-x_{c}\right)\right\}+x_{a} x_{b} x_{c}\left\{{ }^{0} L_{a b c}+{ }^{1} L_{a b c}\left(x_{a}-x_{b}\right)\right\}
\end{aligned}
$$

where $\mathrm{x}$ is the molar fraction, a: $\mathrm{LiBH}_{4}, \mathrm{~b}: \mathrm{NaBH}_{4}, \mathrm{c}: \mathrm{KBH}_{4}$, and $\mathbf{L}=\mathbf{a}+\mathbf{b T}$ parameters contain the interaction parameters for binary and ternary systems.

A ternary interaction parameter was added in the description of the liquid phase, and the calculated eutectic temperature and composition were optimized step by step to obtain a eutectic melting at 102 ${ }^{\circ} \mathrm{C}$.

The ternary interaction parameters necessary to obtain a calculated eutectic melting temperature of $102{ }^{\circ} \mathrm{C}$ turned out to be ${ }^{0} \mathrm{~L}_{\mathrm{abc}}=-14162 \mathrm{~J} / \mathrm{mol}$ and ${ }^{1} \mathrm{~L}_{\mathrm{abc}}=0$ (Table 2). The optimized parameter turned out to be negative, confirming the occurrence of an interaction in the liquid phase for the ternary system, leading to a deep eutectic. The corresponding minima of the liquidus surface are reported in Figure 2 as blue dashed lines. The new ternary eutectic composition is calculated at $0.66 \mathrm{LiBH}_{4-}$ $0.11 \mathrm{NaBH}_{4}-0.23 \mathrm{KBH}_{4}$ and it is shown as a blue square (T3) in Figure 2. The new calculated T3 
Dematteis et al. - Phase diagrams in the $\mathrm{LiBH}_{4}-\mathrm{NaBH}_{4}-\mathrm{KBH}_{4}$ system

composition confirms an excess of $\mathrm{KBH}_{4}$ and $\mathrm{LiBH}_{4}$ in $\mathrm{T} 2$ sample, as suggested by the occurrence of an off-eutectic transformation.

The $0.66 \mathrm{LiBH}_{4}-0.11 \mathrm{NaBH}_{4}-0.23 \mathrm{KBH}_{4}$ composition was investigated by DSC and in-situ SR-PXD and the results are shown Figure 3, where experimental results are compared with the phase fraction calculated from the Calphad assessment. In the middle panel of Figure 3, the calculated molar fraction of phases is reported as a function of temperature, clearly showing the calculated values for the temperature of phase transformations (e.g. polymorphic transitions, eutectic melting, liquidus). These values are in good agreement with the experimental ones. The $\mathrm{LiBH}_{4}$ polymorphic transition is observed at $101{ }^{\circ} \mathrm{C}$ and melting starts at $103{ }^{\circ} \mathrm{C}$. SR-PXD data revealed a liquidus temperature at 111 ${ }^{\circ} \mathrm{C}$ during heating and at $106{ }^{\circ} \mathrm{C}$ during cooling, suggesting the occurrence of an almost pure ternary eutectic mixture, as confirmed by DSC data. The enthalpy of melting of the ternary eutectic mixture is equal to $4.2 \mathrm{~kJ} / \mathrm{mol}$, in reasonable agreement with the calculated value of $5.7 \mathrm{~kJ} / \mathrm{mol}$ (Table 4).

\section{Validation of the assessed pseudo-ternary phase diagram}

The pseudo-ternary phase diagram and corresponding thermodynamic properties were assessed in all temperature and composition ranges, allowing the determination of the $0.66 \mathrm{LiBH}_{4}-0.11 \mathrm{NaBH}_{4}$ $0.23 \mathrm{KBH}_{4}$ ternary eutectic composition, which was experimentally confirmed. From the assessed thermodynamic functions, phase diagram sections related to the samples T50Li, T50Na, and T50K have been obtained, and the results are shown in Figure 4, where experimental and calculated temperatures of phase transformation are compared as a function of composition.

The calculated temperatures for the orthorhombic-to-hexagonal polymorphic transition (black squares, Figure 4) are in good agreement with experiments, as well as for the occurrence of a single cubic solid solution (red circles, Figure 4). The calculated liquidus temperatures are not fully matching the experimental ones (blue triangles, Figure 4), suggesting possible kinetic constraints during SR-PXD measurements. Phase fractions have been calculated as a function of temperature for T50Li, T50Na, and T50K compositions, and they are in good agreement with experimental SX-XRD results, as shown in Figures S2, S3, and S4, respectively. It is worth noting that the temperature for 
Dematteis et al. - Phase diagrams in the $\mathrm{LiBH}_{4}-\mathrm{NaBH}_{4}-\mathrm{KBH}_{4}$ system

the formation of a single-phase cubic solid solution is calculated at $140{ }^{\circ} \mathrm{C}, 146{ }^{\circ} \mathrm{C}$ and $176{ }^{\circ} \mathrm{C}$ for T50Li, T50Na, and T50K compositions, respectively. These values are slightly different from the experimental ones, suggesting possible improvements of the thermodynamic description of the cubic solid solution in the ternary system by the introduction of an interaction parameter. Because of the lacking of experimental data, no further parameters have been considered for this phase.

Furthermore, to validate the thermodynamic assessment of the system, the database was used to calculate various isopleths, i.e. sections of the pseudo-ternary phase diagram at a constant molar fraction of $\mathrm{NaBH}_{4}$ equal to 0.05 (s1-s8, see Table 1 for composition), and new experiments were carried out to confirm the calculations.

The results are presented in Figure 5, together with the first heating and cooling DSC traces of the different mixtures prepared by manual mixing, which promotes the intimate interaction of the parent compounds. It is expected that the results from the manual mixed samples s1-s8 are not different from the ones of ball-milled samples. The calculated isopleths reveal that many phase transformations are taking place in the temperature range from $90{ }^{\circ} \mathrm{C}$ to $120{ }^{\circ} \mathrm{C}$. The onset temperature of the peak recorded on the first heating is observed at $102{ }^{\circ} \mathrm{C}$ for all compositions, in good agreement with the calculated eutectic temperature. The DSC peak is broader for $\mathrm{LiBH}_{4}$-rich samples, suggesting that, apart from melting, other reactions are taking place. The calculations show that the orthorhombic-tohexagonal polymorphic transition is observed, on heating, rather close to beginning of melting.

The area of the DSC peaks is related to the amount of heat required for the phase transformation, and it is proportional to the fraction of eutectic composition that is melting in the sample. Sample s5 presents the biggest peak because the entire sample is melting on heating, while in other samples only a fraction of the mixture is melting crossing the eutectic line. A slight undercooling of the liquid phase is observed on DSC traces measured on cooling.

\section{Conclusions}


Dematteis et al. - Phase diagrams in the $\mathrm{LiBH}_{4}-\mathrm{NaBH}_{4}-\mathrm{KBH}_{4}$ system

The thermodynamics of $\mathrm{LiBH}_{4}-\mathrm{NaBH}_{4}-\mathrm{KBH}_{4}$ ternary system was fully described combining experimental and theoretical investigations. The Calphad method, together with ab-initio calculations to determine the end-members, was used to assess the $\mathrm{LiBH}_{4}-\mathrm{NaBH}_{4}, \mathrm{LiBH}_{4}-\mathrm{KBH}_{4}$, and $\mathrm{NaBH}_{4}-$ $\mathrm{KBH}_{4}$ pseudo-binary phase diagrams. A screening of the ternary system allowed an investigation in all temperature and composition ranges in order to understand which phases could be formed as well as their limit of solubility.

The assessed binary systems are in good agreement with experimental data and the ternary system has been assessed and validated based on new experiments. A reconsideration of the thermodynamic description of the liquid phase of pure $\mathrm{NaBH}_{4}$, together with the reassessment of the $\mathrm{LiBH}_{4}-\mathrm{NaBH}_{4}$ system, has been necessary, confirming the importance to obtain reliable data for the enthalpy of melting of pure compounds, in order to describe binary or ternary mixtures. In the case of $\mathrm{KBH}_{4}$, the enthalpy of mixing was not known, but it has been obtained by a combined assessment of different binary systems $\left(\mathrm{LiBH}_{4}-\mathrm{KBH}_{4}\right.$, and $\left.\mathrm{NaBH}_{4}-\mathrm{KBH}_{4}\right)$, and a melting enthalpy of $19.2 \mathrm{~kJ} / \mathrm{mol}$ has been estimated for the first time. Negative enthalpies of mixing or low positive value have been obtained for the liquid phase, suggesting attractive interactions among ions in the molten state. On the other hand, positive or close-to-zero enthalpy of mixing have been calculated for the solid solutions, suggesting a combined role of electronic and size effects in the solubility among borohydrides.

In conclusion, it has been demonstrated that a combined use of ab-initio and Calphad thermodynamic calculations, supported and confirmed by experimental measurements, is a powerful tool for a complete description of thermodynamic properties of mixtures of borohydrides. An estimation of the decomposition reactions in the investigated system can be obtained with the current optimised database. However, it should be coupled with experimental evaluation of decomposition products.

\section{Acknowledgement}


Dematteis et al. - Phase diagrams in the $\mathrm{LiBH}_{4}-\mathrm{NaBH}_{4}-\mathrm{KBH}_{4}$ system

Financial support from the European Fuel Cells and Hydrogen Joint Undertaking in the framework of the BOR4STORE (Grant agreement $n^{\circ}$ 303428) is thankfully acknowledged. The work was supported by The Innovation Fund Denmark, via the research project HyFillFast, the Danish National Research Foundation, Center for Materials Crystallography (DNRF93), and by the Danish Research Council for Nature and Universe (Danscatt). The Erasmus Traineeship Programme is gratefully acknowledged for the financial support in the exchange mobility period between the Aarhus University and the University of Turin. The access to all the beamlines and the beam scientists of the synchrotron facilities are thankfully acknowledged.

\section{Supporting Information Description}

Additional ternary compositions plot, list and details of synchrotron facilities, additional plots of SRPXD, DSC, calculated amount of phases and pseudo-binary phase diagrams (CALPHAD) for all the investigated samples. 
Dematteis et al. - Phase diagrams in the $\mathrm{LiBH}_{4}-\mathrm{NaBH}_{4}-\mathrm{KBH}_{4}$ system

\section{References}

1 B. Sakituna, F. Lamaridarkrim and M. Hirscher, Int. J. Hydrogen Energy, 2007, 32, 1121-1140.

2 M. B. Ley, L. H. Jepsen, Y.-S. Lee, Y. W. Cho, J. M. Bellosta von Colbe, M. Dornheim, M. Rokni, J. O. Jensen, M. Sloth, Y. E. Filinchuk, J. E. Jørgensen, F. Besenbacher and T. R. Jensen, Mater. Today, 2014, 17, $122-128$. H. W. Li, Y. Yan, S. I. Orimo, A. Züttel and C. M. Jensen, Energies, 2011, 4, 185-214.

4 E. Callini, Z. Ö. K. Atakli, B. C. Hauback, S. I. Orimo, C. Jensen, M. Dornheim, D. Grant, Y. W. Cho, P. Chen, B. Hjörvarsson, P. de Jongh, C. Weidenthaler, M. Baricco, M. Paskevicius, T. R. Jensen, M. E. Bowden, T. S. Autrey and A. Züttel, Appl. Phys. A, 2016, 122, 353

M. Paskevicius, L. H. Jepsen, P. Schouwink, R. Černý, D. B. Ravnsbæk, Y. Filinchuk, M. Dornheim, F. Besenbacher and T. R. Jensen, Chem. Soc. Rev., 2017, 46, 1565-1634.

L. H. Rude, T. K. Nielsen, D. B. Ravnsbæk, U. Bösenberg, M. B. Ley, B. Richter, L. M. Arnbjerg, M. Dornheim, Y. E. Filinchuk, F. Besenbacher and T. R. Jensen, Phys. status solidi, 2011, 208, 1754-1773.

D. B. Ravnsbæk and T. R. Jensen, J. Phys. Chem. Solids, 2010, 71, 1144-1149. Angew. Chemie Int. Ed., 2008, 47, 2817-2819. M. Paskevicius, M. B. Ley, D. A. Sheppard, T. R. Jensen and C. E. Buckley, Phys. Chem. Chem. Phys., 2013, 15, 19774.

X. Liu, D. Peaslee, T. P. Sheehan and E. H. Majzoub, J. Phys. Chem. C, 2014, 118, 27265-27271.

H. S. Lee, Y.-S. Lee, J.-Y. Suh, M. Kim, J.-S. Yu and Y. W. Cho, J. Phys. Chem. C, 2011, 115, 20027-20035.

P. Javadian, D. A. Sheppard, C. E. Buckley and T. R. Jensen, Int. J. Hydrogen Energy, 2015, 11, 96-103.

R. Gosalawit-Utke, T. K. Nielsen, I. Saldan, D. Laipple, Y. Cerenius, T. R. Jensen, T. Klassen and M. Dornheim, J. Phys. Chem. C, 2011, 115, 10903-10910. and M. Baricco, J. Alloys Compd., 2013, 580, S282-S286. G. N. Kalantzopoulos, J. G. Vitillo, E. Albanese, E. R. Pinatel, B. Civalleri, S. Deledda, S. Bordiga, M. Baricco and B. C. Hauback, J. Alloys Compd., 2014, 615, S702-S705. A. El Kharbachi, E. R. Pinatel, I. Nuta and M. Baricco, Calphad, 2012, 39, 80-90.

E. R. Pinatel, E. Albanese, B. Civalleri and M. Baricco, J. Alloys Compd., 2015, 645, S64-S68.

J. E. Fonneløp, M. Corno, H. Grove, E. R. Pinatel, M. H. Sørby, P. Ugliengo, M. Baricco and B. C. Hauback, J. Alloys Compd., 2011, 509, 10-14.

O. Zavorotynska, M. Corno, E. R. Pinatel, L. H. Rude, P. Ugliengo, T. R. Jensen and M. Baricco, Crystals, 2012, 2, 144-158.

E. M. Dematteis, E. Roedern, E. R. Pinatel, M. Corno, T. R. Jensen and M. Baricco, RSC Adv., 2016, 6, 6010160108.

M. B. Ley, E. Roedern and T. R. Jensen, Phys. Chem. Chem. Phys., 2014, 16, 24194-24199.

G. F. Huff, US 2.935.428, 1960.

R. M. Adams, Adv. Chem., 1961, 32, 60-68.

K. N. Semenenko, A. P. Chavgun and V. N. Surov, Russ. J. Inorg. Chem., 1971, 16, 271-273.

Y. Cerenius, K. Ståhl, L. A. Svensson, T. Ursby, ̊. Oskarsson, J. Albertsson and A. Liljas, J. Synchrotron Radiat., 2000, 7, 203-208.

T. R. Jensen, T. K. Nielsen, Y. E. Filinchuk, J. E. Jørgensen, Y. Cerenius, E. M. Gray and C. J. Webb, J. Appl. Crystallogr., 2010, 43, 1456-1463.

A. P. Hammersley, S. O. Svensson, M. Hanfland, A. N. Fitch and D. Hausermann, High Press. Res., 1996, 14, 235-248.

R. Dovesi, V. R. Saunders, C. Roetti, R. Orlando, C. M. Zicovich-Wilson, F. Pascale, B. Civalleri, K. Doll, N. M. Harrison, I. J. Bush, P. D’Arco, M. Llunell, M. Causà and Y. Noël, CRYSTAL14 User's Manual, University of Torino, 2014.

R. Dovesi, R. Orlando, A. Erba, C. M. Zicovich-Wilson, B. Civalleri, S. Casassa, L. Maschio, M. Ferrabone, M. De La Pierre, P. D’Arco, Y. Noël, M. Causà, M. Rérat and B. Kirtman, Int. J. Quantum Chem., 2014, 114, 12871317. 18890-18900.

F. Pascale, C. M. Zicovich-Wilson, F. Lopez Gejo, B. Civalleri, R. Orlando and R. Dovesi, J. Comput. Chem., 2004, 25, 888-897. 
Dematteis et al. - Phase diagrams in the $\mathrm{LiBH}_{4}-\mathrm{NaBH}_{4}-\mathrm{KBH}_{4}$ system

37 C. M. Zicovich-Wilson, F. J. Torres, F. Pascale, L. Valenzano, R. Orlando and R. Dovesi, J. Comput. Chem., 2008, 29, 2268-2278.

38 M. Corno, E. R. Pinatel, P. Ugliengo and M. Baricco, J. Alloys Compd., 2011, 509, S679-S683.

39 J. O. Andersson, T. Helander, L. Hoglund, P. Shi and B. Sundman, Calphad, 2002, 26, $273-312$.

40 A. T. Dinsdale, Calphad, 1991, 15, 317-425.

41 SGTE Subst. database V 4.1. - http//www.crct.polymtl.ca/fact/documentation/sgps_list.htm.

42 A. T. Kister and O. Redlich, Ind. Eng. Chem., 1948, 40, 345-348.

43 E. R. Pinatel, PhD Thesis, Univ. Turin, 2012, Thermodynamic Modelling of Hydrogen Storage Materi.

44 C. Milanese, S. Garroni, A. Girella, G. Mulas, V. Berbenni, G. Bruni, S. Suriñach, M. D. Baró and A. Marini, J. Phys. Chem. C, 2011, 115, 3151-3162.

45 D. S. Stasinevich and G. A. Egorenko, Russ. J. Inorg. Chem., 1968, 13, 341-343.

46 K. C. Kim and D. S. Sholl, J. Phys. Chem. C, 2010, 114, 678-686.

47 H. L. Lukas, S. G. Fries and B. Sundman, Computational thermodynamics, the calphad method, 2007.

48 M. Yves-Marie, M. Gambino and J.-P. Bros, J. Chim. Phys., 1975, 72, 83-88. 
Dematteis et al. - Phase diagrams in the $\mathrm{LiBH}_{4}-\mathrm{NaBH}_{4}-\mathrm{KBH}_{4}$ system

\section{FIGURE CAPTIONS}

Figure 1 - Literature data and assessed phase diagrams for the $\mathrm{NaBH}_{4}-\mathrm{KBH}_{4}$ (a), $\mathrm{LiBH}_{4}-\mathrm{NaBH}_{4}$ (b), $\mathrm{LiBH}_{4}-\mathrm{KBH}_{4}$ (c) systems. ( $\mathrm{SS}=$ Temperature of miscibility gap in the solid solution, $\mathrm{M}=$ Melting temperature of the solid solution, $\mathrm{LIQ}=$ Liquidus temperature, $\mathrm{EU}=$ Eutectic melting temperature, $\mathrm{PT}=$ Polymorphic Transision temperature, $\mathrm{LiK}=$ temperature of decomposition of the bimetallic $\mathrm{LiK}\left(\mathrm{BH}_{4}\right)_{2}$ compound, TPPA = Temperature Programmed Photographic Analysis temperature data, $\mathrm{DSC}=$ Differential Scanning Calorimetry temperature data, SR-PXD $=$ Synchrotron Radiation Powder X-ray Diffraction temperature data, HT-PXD = High Temperature Powder X-ray Diffrction temperature data, CALPHAD = calculated phase diagram).

Figure 2 - Calculated minima of the liquidus surface for the $\mathrm{LiBH}_{4}-\mathrm{NaBH}_{4}-\mathrm{KBH}_{4}$ system. Solid black lines and circle: simple extrapolation of binary systems; dashed blue lines and square: including a ternary interaction parameter $\left(\mathrm{TER}^{0} \mathrm{~L}_{\mathrm{liq}}\right.$ ) for the liquid phase equal to $-14162 \mathrm{~J} / \mathrm{mol}$. Literature datum (triangular red point) is also reported for comparison. $(\mathrm{CUB} \# 1$ and $\mathrm{CUB} \# 2=$ cubic phases, $\mathrm{ORT}=$ orthorhombic phase, HEX = hexagonal phase)

Figure 3 - DSC (left), amount of calculated molar fraction of phases (CALPHAD, middle) and SRPXD patterns (right) of sample T3, $0.66 \mathrm{LiBH}_{4}-0.11 \mathrm{NaBH}_{4}-0.23 \mathrm{KBH}_{4}(\lambda=0.7129 \AA, \Delta \mathrm{T} / \Delta \mathrm{t}=5$ ${ }^{\circ} \mathrm{C} / \mathrm{min}$, argon atmosphere, $2^{\text {nd }}$ cycle of heating (a) and cooling (b)). (ORT $=$ orthorhombic phase, HEX = hexagonal phase, CUB\#1 and CUB\#2 = cubic phases, LIQ = liquid phase)

Figure 4 - Comparison between experimental data of mixtures T50Li, T50Na, T50K and calculated pseudo-binary phase diagrams (CALPHAD), section at constant composition of one component. (PT $=$ Polymorphic Transition, EU $=$ Eutectic melting, SS end $=$ upper critical solution temperature, end of the miscibility gap and starting of single phase solid solution region, LIQ = Liquid phase) 
Dematteis et al. - Phase diagrams in the $\mathrm{LiBH}_{4}-\mathrm{NaBH}_{4}-\mathrm{KBH}_{4}$ system

Figure 5 - Comparison between calculated isopleths for the $\mathrm{LiBH}_{4}-\mathrm{NaBH}_{4}-\mathrm{KBH}_{4}$ system at constant composition $\left(\mathrm{xNaBH}_{4}=0.05\right)(\mathrm{CALPHAD}$, middle $)$ and experimental data of mixtures s1-s8. DSC traces during $1^{\text {st }}$ heating (right) and cooling (left), $\Delta \mathrm{T} / \Delta \mathrm{t}=5{ }^{\circ} \mathrm{C} / \mathrm{min}, 40 \mathrm{ml} / \mathrm{min}$ argon flow.

\section{TABLE CAPTION}

Table $1 \quad-\quad$ Investigated compositions in the ternary system. $\mathrm{M}=$ Manual mixing; $\mathrm{BM}=$ Ball Milled.

Table 2 - Assessed excess Gibbs free energy functions for all investigated systems.

Table 3 - Gibbs Free Energy for the liquid phase of $\mathrm{NaBH}_{4}, \mathrm{KBH}_{4}$ and Gibbs free energy for the bimetallic compound $\mathrm{LiK}\left(\mathrm{BH}_{4}\right)_{2}$.

Table 4 -Comparison of experimental and calculated data of composition, melting temperatures and enthalpies for eutectics or minimum in the ternary $\mathrm{LiBH}_{4}-\mathrm{NaBH}_{4}-\mathrm{KBH}_{4}$ system.

Table 5 - All ab-initio calculated Gibbs free energy of end members for the compounds involved in the ternary $\mathrm{LiBH}_{4}-\mathrm{NaBH}_{4}-\mathrm{KBH}_{4}$ system. 
Dematteis et al. - Phase diagrams in the $\mathrm{LiBH}_{4}-\mathrm{NaBH}_{4}-\mathrm{KBH}_{4}$ system

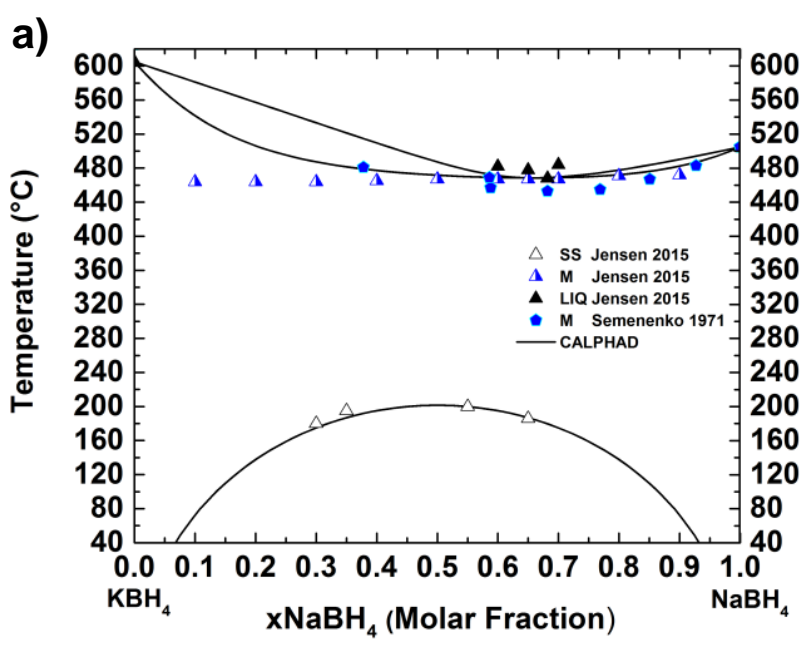

b)
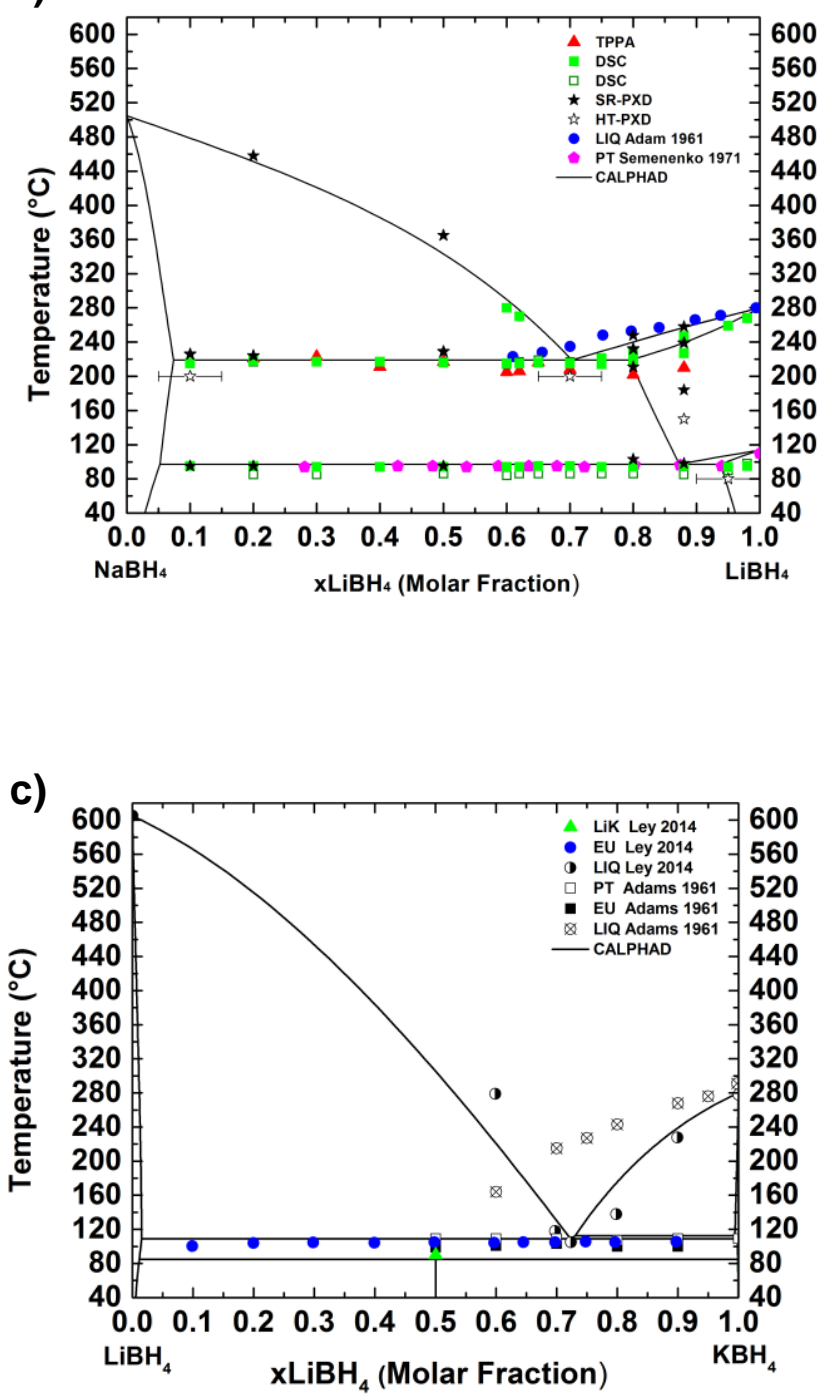
Figure 6 - Literature data and assessed phase diagrams for the $\mathrm{NaBH}_{4}-\mathrm{KBH}_{4}(\mathrm{a})$, $\mathrm{LiBH}_{4}-\mathrm{NaBH}_{4}(\mathrm{~b}), \mathrm{LiBH}_{4}-\mathrm{KBH}_{4}$ (c) systems. (SS = Temperature of miscibility gap in the solid solution, $M=$ Melting temperature of the solid solution, $L I Q=$ Liquidus temperature, $E U=$ Eutectic melting temperature, $\mathrm{PT}=$ Polymorphic Transision temperature, $\mathrm{LiK}=$ temperature of decomposition of the bimetallic $\mathrm{LiK}\left(\mathrm{BH}_{4}\right)_{2}$ compound, TPPA = Temperature Programmed

Photographic Analysis temperature data, DSC = Differential Scanning Calorimetry temperature data, SR-PXD = Synchrotron Radiation Powder X-ray Diffraction temperature data, HT-PXD = High Temperature Powder X-ray Diffrction temperature data, CALPHAD = calculated phase diagram).

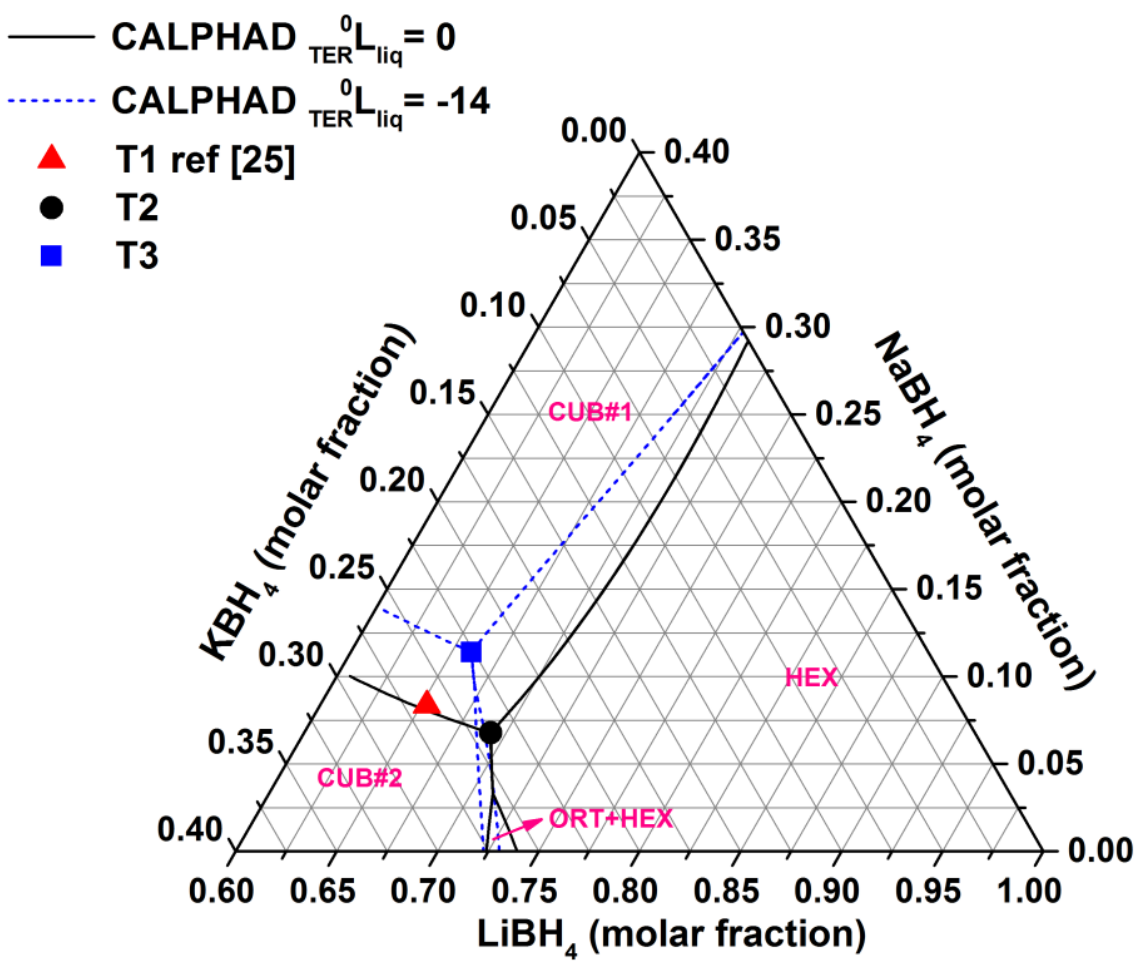

Figure 7 - Calculated minima of the liquidus surface for the $\mathrm{LiBH}_{4}-\mathrm{NaBH}_{4}-\mathrm{KBH}_{4} \mathrm{System}_{\text {. }}$ Solid black lines and circle: simple extrapolation of binary systems; dashed blue lines and square: including a ternary interaction parameter $\left(\operatorname{TER}^{0} \mathrm{Lliq}_{\mathrm{iq}}\right)$ for the liquid phase equal to - 
$14162 \mathrm{~J} / \mathrm{mol}$. Literature datum (triangular red point) is also reported for comparison. (CUB\#1 and CUB\#2 = cubic phases, ORT = orthorhombic phase, HEX = hexagonal phase)

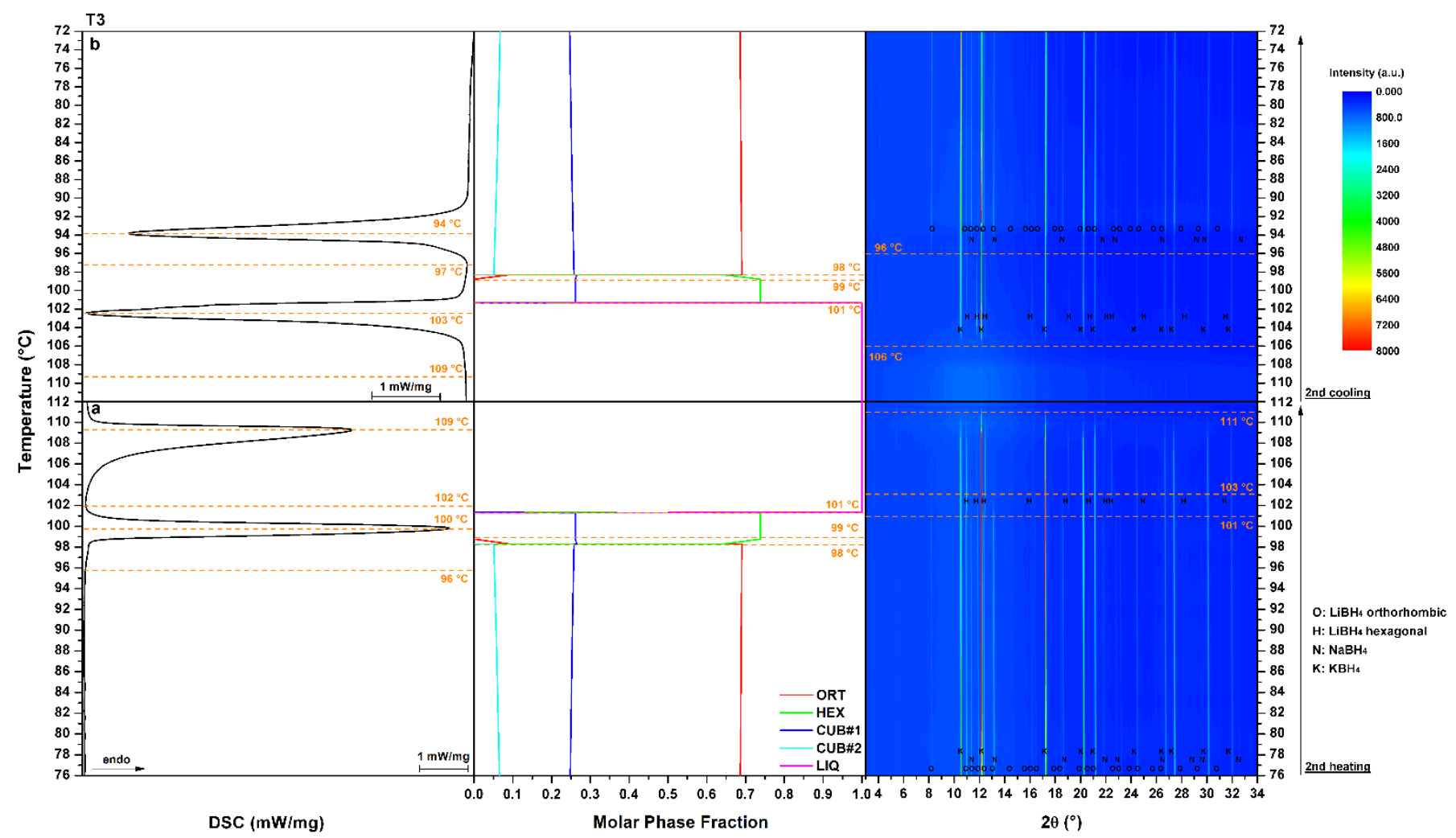

Figure 8 - DSC (left), amount of calculated molar fraction of phases (CALPHAD, middle) and SR-PXD patterns (right) of sample T3, 0.66 $\mathrm{LiBH}_{4}-0.11 \mathrm{NaBH}_{4}-0.23 \mathrm{KBH}_{4}(\lambda=0.7129 \AA, \Delta \mathrm{T} / \Delta \mathrm{t}$ $=5{ }^{\circ} \mathrm{C} / \mathrm{min}$, argon atmosphere, $2^{\text {nd }}$ cycle of heating (a) and cooling (b)). $(\mathrm{ORT}=$ orthorhombic phase, HEX = hexagonal phase, CUB\#1 and CUB\#2 = cubic phases, LIQ = liquid phase) 
Dematteis et al. - Phase diagrams in the $\mathrm{LiBH}_{4}-\mathrm{NaBH}_{4}-\mathrm{KBH}_{4}$ system
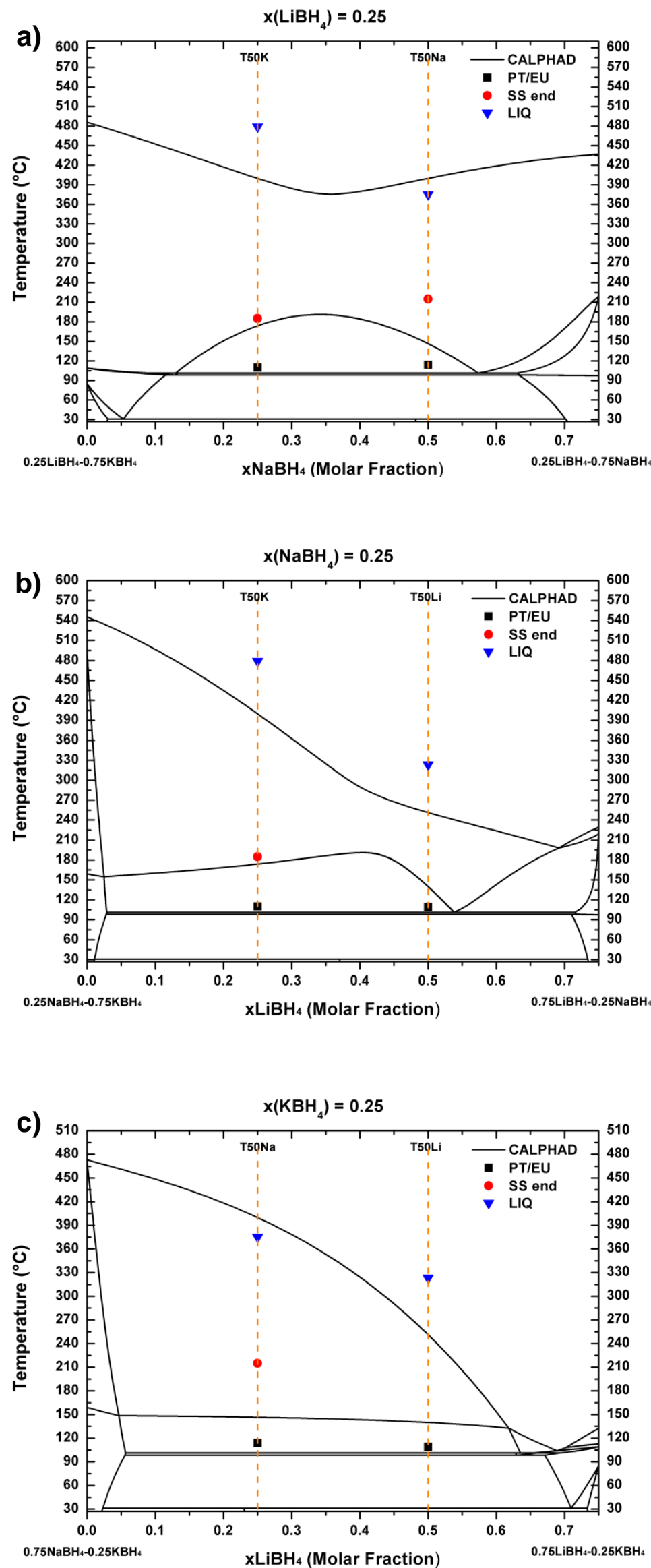
Figure 9 - Comparison between experimental data of mixtures $\mathrm{T50Li}$, T50Na, T50K and calculated pseudo-binary phase diagrams (CALPHAD), section at constant composition of one component. $(\mathrm{PT}=$ Polymorphic Transition, $\mathrm{EU}=$ Eutectic melting, $\mathrm{SS}$ end $=$ upper critical solution temperature, end of the miscibility gap and starting of single phase solid solution region, $\mathrm{LIQ}=$ Liquid phase)

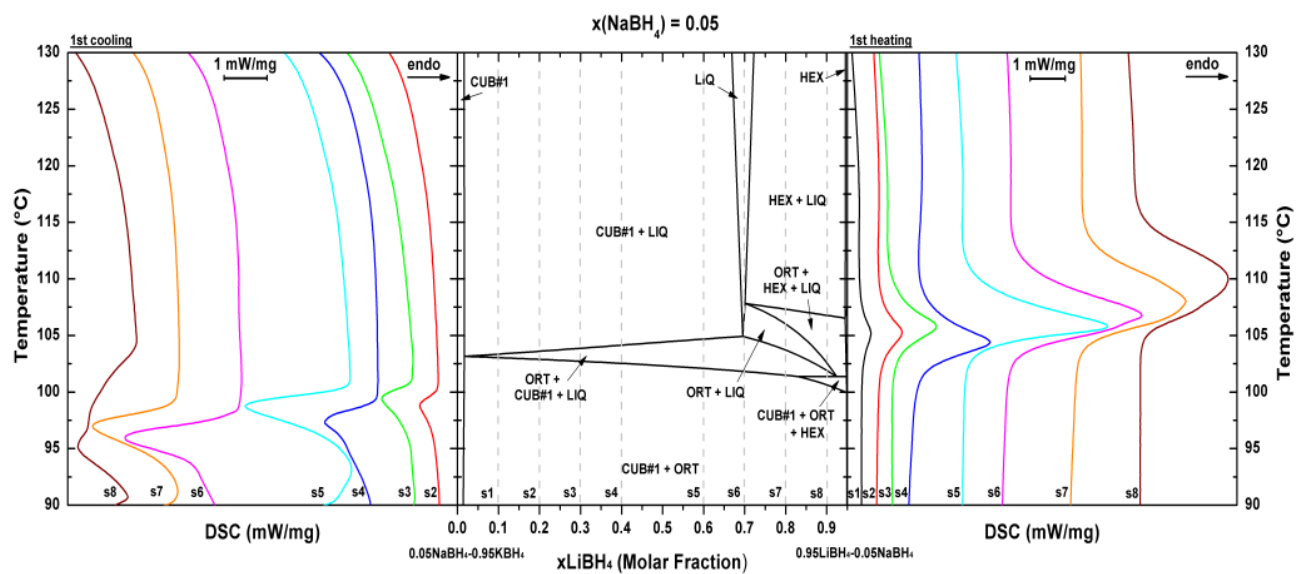

Figure 10 - Comparison between calculated isopleths for the $\mathrm{LiBH}_{4}-\mathrm{NaBH}_{4}-\mathrm{KBH}_{4}$ system at constant composition $\left(\mathrm{xNaBH}_{4}=\mathbf{0 . 0 5}\right)(\mathrm{CALPHAD}$, middle $)$ and experimental data of mixtures s1-s8. DSC traces during $1^{\text {st }}$ heating (right) and cooling (left), $\Delta \mathrm{T} / \Delta \mathrm{t}=5^{\circ} \mathrm{C} / \mathrm{min}, 40$ $\mathrm{ml} / \mathrm{min}$ argon flow. 
Dematteis et al. - Phase diagrams in the $\mathrm{LiBH}_{4}-\mathrm{NaBH}_{4}-\mathrm{KBH}_{4}$ system

Table 6 - Investigated compositions in the ternary system.

M = Manual mixing; $\mathbf{B M}=$ Ball Milled.

\begin{tabular}{|l|c|l|}
\hline Sample & $\begin{array}{c}\text { Composition } \\
\text { (Molar Fraction) }\end{array}$ & Synthesis \\
\hline T50Li & $0.50 \mathrm{LiBH}_{4}-0.25 \mathrm{NaBH}_{4}-0.25 \mathrm{KBH}_{4}$ & BM \\
\hline T50Na & $0.25 \mathrm{LiBH}_{4}-0.50 \mathrm{NaBH}_{4}-0.25 \mathrm{KBH}_{4}$ & BM \\
\hline T50K & $0.25 \mathrm{LiBH}_{4}-0.25 \mathrm{NaBH}_{4}-0.50 \mathrm{KBH}_{4}$ & BM \\
\hline T1 & $0.65 \mathrm{LiBH}_{4}-0.08 \mathrm{NaBH}_{4}-0.27 \mathrm{KBH}_{4}$ & BM \\
\hline T2 & $0.68 \mathrm{LiBH}_{4}-0.08 \mathrm{NaBH}_{4}-0.24 \mathrm{KBH}_{4}$ & BM \\
\hline T3 & $0.66 \mathrm{LiBH}_{4}-0.11 \mathrm{NaBH}_{4}-0.23 \mathrm{KBH}_{4}$ & BM \\
\hline s1 & $0.10 \mathrm{LiBH}_{4}-0.05 \mathrm{NaBH}_{4}-0.85 \mathrm{KBH}_{4}$ & $\mathrm{M}$ \\
\hline s2 & $0.20 \mathrm{LiBH}_{4}-0.05 \mathrm{NaBH}_{4}-0.75 \mathrm{KBH}_{4}$ & $\mathrm{M}$ \\
\hline s3 & $0.30 \mathrm{LiBH}_{4}-0.05 \mathrm{NaBH}_{4}-0.65 \mathrm{KBH}_{4}$ & $\mathrm{M}$ \\
\hline s4 & $0.40 \mathrm{LiBH}_{4}-0.05 \mathrm{NaBH}_{4}-0.55 \mathrm{KBH}_{4}$ & $\mathrm{M}$ \\
\hline s5 & $0.60 \mathrm{LiBH}_{4}-0.05 \mathrm{NaBH}_{4}-0.35 \mathrm{KBH}_{4}$ & $\mathrm{M}$ \\
\hline s6 & $0.70 \mathrm{LiBH}_{4}-0.05 \mathrm{NaBH}_{4}-0.25 \mathrm{KBH}_{4}$ & $\mathrm{M}$ \\
\hline s7 & $0.80 \mathrm{LiBH}_{4}-0.05 \mathrm{NaBH}_{4}-0.15 \mathrm{KBH}_{4}$ & $\mathrm{M}$ \\
\hline s8 & $0.90 \mathrm{LiBH}_{4}-0.05 \mathrm{NaBH}_{4}-0.05 \mathrm{KBH}_{4}$ & $\mathrm{M}$ \\
\hline
\end{tabular}


Table 7 - Assessed excess Gibbs free energy functions for all investigated systems.

\begin{tabular}{|c|}
\hline Assessed Excess Gibbs Free Energy (J/mol) \\
\hline$\underline{\mathrm{LiBH}_{4}-\mathrm{NaBH}} \underline{H}_{4}$ \\
\hline $\begin{aligned} \mathrm{LIQ}_{G}{ }^{\mathrm{exc}}= & \mathrm{X}_{\mathrm{LiBH} 4} \cdot \mathbf{X}_{\mathrm{NaBH} 4} \cdot(-11291+17 \cdot \mathrm{T})+\mathbf{X}_{\mathrm{LiBH} 4} \cdot \mathbf{X}_{\mathrm{NaBH} 4} \cdot\left(\mathrm{X}_{\mathrm{LiBH} 4}-\right. \\
& \left.\mathrm{X}_{\mathrm{NaBH} 4}\right)(-308)\end{aligned}$ \\
\hline${ }^{\mathrm{CUB}} \mathbf{G}^{\mathrm{exc}}=\mathrm{X}_{\mathrm{LiBH} 4} \cdot \mathrm{X}_{\mathrm{NaBH} 4} \cdot(5887)$ \\
\hline${ }^{\mathrm{ORT}} G^{\mathrm{exc}}={ }^{\mathrm{HEX}_{G}} \mathbf{G}^{\mathrm{exc}}=0$ \\
\hline$\underline{\mathrm{LBHH}_{4}-\mathrm{KBH}_{4}}$ \\
\hline${ }^{\mathrm{LIQ}_{\mathrm{G}}}{ }^{\mathrm{exc}}=\mathrm{X}_{\mathrm{LiBH} 4} \cdot \mathrm{X}_{\mathrm{KBH} 4} \cdot(-13016)$ \\
\hline${ }^{\mathrm{CUB}} \mathbf{G}^{\mathrm{exc}}=\mathrm{X}_{\mathrm{LiBH} 4} \cdot \mathbf{X}_{\mathrm{KBH} 4} \cdot(\mathbf{1 0 0 0 0})$ \\
\hline${ }^{\mathrm{ORT}_{G}} \mathbf{G}^{\mathrm{exc}}={ }^{\mathrm{HEX}_{\mathrm{G}}}{ }^{\mathrm{exc}}=\mathrm{X}_{\mathrm{LiBH} 4} \cdot \mathrm{X}_{\mathrm{KBH} 4} \cdot(\mathbf{5 0 0 0})$ \\
\hline$\underline{\mathrm{NaBH}_{4}-\mathrm{KBH}_{4}}$ \\
\hline${ }^{\mathrm{LIQ}_{G}}{ }^{\mathrm{exc}}=\mathrm{X}_{\mathrm{NaBH} 4} \cdot \mathrm{X}_{\mathrm{KBH} 4} \cdot(\mathbf{1 0 5 6})$ \\
\hline${ }^{\mathrm{CUB}^{-}} \mathbf{G}^{\mathrm{exc}}=\mathbf{X}_{\mathrm{NaBH} 4} \cdot \mathbf{X}_{\mathrm{KBH} 4} \cdot(\mathbf{7 8 9 3})$ \\
\hline${ }^{\mathrm{ORT}_{G}}{ }^{\mathrm{exc}}={ }^{\mathrm{HEX}} \mathbf{G}^{\mathrm{exc}}=\mathrm{X}_{\mathrm{NaBH}} \cdot \mathrm{X}_{\mathrm{KBH} 4} \cdot(10000)$ \\
\hline$\underline{\mathrm{LiBH}}_{4}-\underline{\mathrm{NaBH}}_{4}-\underline{K B H}_{4}$ \\
\hline 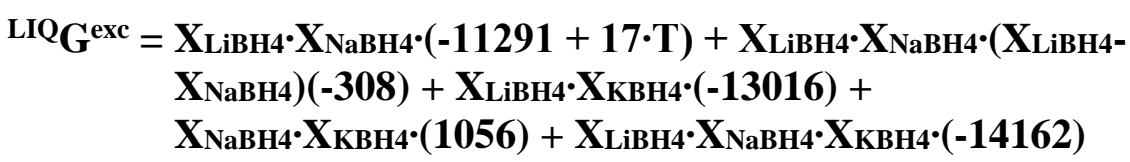 \\
\hline
\end{tabular}


Dematteis et al. - Phase diagrams in the $\mathrm{LiBH}_{4}-\mathrm{NaBH}_{4}-\mathrm{KBH}_{4}$ system

Table 8 - Gibbs Free Energy for the liquid phase of $\mathrm{NaBH}_{4}, \mathrm{KBH}_{4}$ and Gibbs free energy for the bimetallic compound $\operatorname{LiK}\left(\mathrm{BH}_{4}\right)_{2}$.

\begin{tabular}{|c|c|}
\hline Gibbs free energy $(\mathrm{J} / \mathrm{mol})$ & Temperature Range $\left({ }^{\circ} \mathrm{C}\right)$ \\
\hline${ }^{{ }^{L}} G\left(\mathrm{NaBH}_{4}\right)={ }^{\mathrm{CUB}} \mathrm{G}\left(\mathrm{NaBH}_{4}\right)+16926-21.756 \cdot \mathrm{T}$ & RT-505 \\
\hline${ }^{\mathrm{LIQ}} \mathrm{G}(\mathrm{NaBH})=-217735+693 \cdot \mathrm{T}-119.233 \cdot \mathrm{T} \cdot \mathrm{Ln}(\mathrm{T})$ & $505-1000$ \\
\hline 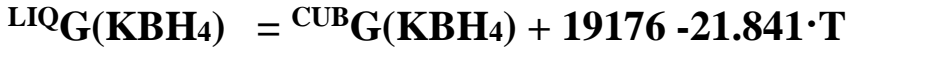 & RT-1000 \\
\hline $\begin{array}{l}\mathrm{G}\left(\mathrm{LiK}_{\left.\left(\mathrm{BH}_{4}\right)_{2}\right)}={ }^{\mathrm{CUB}} \mathrm{G}\left(\mathrm{LiBH}_{4}\right)+{ }^{\mathrm{CUB}} \mathrm{G}\left(\mathrm{KBH}_{4}\right)-1300\right. \\
+3.53 \cdot \mathrm{T}\end{array}$ & RT-1000 \\
\hline
\end{tabular}


Table 9 - Comparison of experimental and calculated data of composition, melting temperatures and enthalpies for eutectics or minimum in the ternary $\mathrm{LiBH}_{4}-\mathrm{NaBH}_{4}-\mathrm{KBH}_{4}$ system.

\begin{tabular}{cc}
\hline Experimental & Calculated \\
\hline
\end{tabular}

\section{$\underline{\mathrm{LiBH}}_{4}-\underline{\mathrm{NaBH}}_{4}$}

Ref. [23]

$\mathrm{T}=216{ }^{\circ} \mathrm{C}$

$70.0 \mathrm{~mol} \% \mathrm{LiBH}_{4}$

$\Delta H_{\text {melt }}=6990 \mathrm{~J} / \mathrm{mol}$
$\mathrm{T}=219^{\circ} \mathrm{C}$

$70.3 \mathrm{~mol}_{\%} \mathrm{LiBH}_{4}$

$\Delta H_{\text {melt }}=6520 \mathrm{~J} / \mathrm{mol}$

\section{$\underline{\mathrm{LiBH}}_{4}-\underline{K B H}_{4}$}

Ref. [24]

$\mathrm{T}=104{ }^{\circ} \mathrm{C}$

$72.5 \mathrm{~mol}_{\%} \mathrm{LiBH}_{4}$

$\mathrm{T}=109{ }^{\circ} \mathrm{C}$

$\Delta H_{\text {melt }}=11025 \mathrm{~J} / \mathrm{mol}$

$72.3 \mathrm{~mol}_{\%} \mathrm{LiBH}_{4}$

$\Delta H_{\text {melt }}=9828 \mathrm{~J} / \mathrm{mol}$

$\underline{\mathrm{NaBH}_{4}-\mathrm{KBH}_{4}}$

$\mathrm{T}=462{ }^{\circ} \mathrm{C}$

$68.2 \mathrm{~mol}_{\%} \mathrm{NaBH}_{4}$

$\mathrm{T}=468{ }^{\circ} \mathrm{C}$

$\Delta H_{\text {melt }}=17028 \mathrm{~J} / \mathrm{mol}$

$68.2 \mathrm{~mol}_{\%} \mathrm{NaBH}_{4}$

$\Delta H_{\text {melt }}=15331 \mathrm{~J} / \mathrm{mol}$

\section{$\underline{\mathrm{LiBH}}_{4}-\mathrm{NaBH}_{4}-\mathrm{KBH}_{4}$}

$\mathrm{T}=103{ }^{\circ} \mathrm{C}$

$\mathrm{T}=101{ }^{\circ} \mathrm{C}$

0.66LiBH4-0.11NaBH4-0.23KBH $4 \quad 0.66 \mathrm{LiBH}_{4}-0.11 \mathrm{NaBH}_{4}-0.23 \mathrm{KBH}_{4}$

$\Delta H_{\text {melt }}=4155 \mathrm{~J} / \mathrm{mol}$

$\Delta H_{\text {melt }}=5701 \mathrm{~J} / \mathrm{mol}$ 
Dematteis et al. - Phase diagrams in the $\mathrm{LiBH}_{4}-\mathrm{NaBH}_{4}-\mathrm{KBH}_{4}$ system

Table 10 - All ab-initio calculated Gibbs free energy of end members for the compounds involved in the ternary $\mathrm{LiBH}_{4}-\mathrm{NaBH}_{4}-\mathrm{KBH}_{4}$ system.

\begin{tabular}{|c|c|}
\hline \multicolumn{2}{|c|}{ Gibbs free energy $(\mathrm{J} / \mathrm{mol})$} \\
\hline${ }^{\mathrm{CUB}} \mathrm{G}\left(\mathrm{LiBH}_{4}\right)=\mathbf{G}\left(\mathrm{LiBH}_{4}\right)+3600$ & ref. [23] \\
\hline $\mathrm{ORT}_{G}\left(\mathrm{NaBH}_{4}\right)=\mathrm{G}\left(\mathrm{NaBH}_{4}\right)+8400$ & ref. [23] \\
\hline $\operatorname{HEX}_{G}\left(\mathrm{NaBH}_{4}\right)=\mathrm{G}\left(\mathrm{NaBH}_{4}\right)+6200$ & ref. [23] \\
\hline \multicolumn{2}{|l|}{${ }^{\mathrm{ORT}} \mathbf{G}\left(\mathrm{KBH}_{4}\right)=\mathbf{G}\left(\mathrm{KBH}_{4}\right)+15200$} \\
\hline $\operatorname{HEX}_{G}\left(\mathrm{KBH}_{4}\right)=\mathbf{G}\left(\mathrm{KBH}_{4}\right)+11100$ & \\
\hline
\end{tabular}

